\title{
Quantitative ultrasound at the hand phalanges in adolescent boys in relation to their pubertal development and physical efficiency
}

\author{
Właściwości ultradźwiękowe kości paliczków rąk u dorastających chłopców \\ w zależności od stopnia dojrzałości płciowej i sprawności fizycznej
}

\author{
Agnieszka Chwałczyńska', Wojciech Pluskiewicz ${ }^{2}$, Joanna Syrycka ${ }^{1,3}$, Marek Bolanowski ${ }^{3}$ \\ ${ }^{1}$ Department of the Principles of Physiotherapy, University of Physical Education, Wroctaw, Poland \\ ${ }^{2}$ Department and Clinic of Internal Diseases, Diabetology and Nephrology, Metabolic Bone Diseases Unit, \\ Medical University of Silesia, Katowice, Poland \\ ${ }^{3}$ Department of Endocrinology, Diabetology and Isotope Therapy, Medical University, Wroclaw, Poland
}

\begin{abstract}
Introduction: Our aim was to assess the ultrasound properties of bone measured at hand phalanges in 55 adolescent boys aged 13-15 years regarding the influence of pubertal status and level of physical efficiency including muscular strength.

Material and methods: They were divided into two age groups: Group I ( $\mathrm{n}=37$, boys aged 159-171 months) and Group II $(\mathrm{n}=18$, aged 172-184 months). The controls were 94 boys matched for age, recruited from 1,256 subjects undergoing bone measurement for screening purposes. The skeletal status (amplitude-dependent speed of sound - Ad-SoS) was assessed by quantitative ultrasound (QUS) at proximal phalanges with the use of DBM Sonic 1200. Physical efficiency was assessed using Zuchora's test, and pubertal development by Tanner's score.

Results: There was no difference in mean Ad-SoS between the entire study group and controls. Ad-SoS values were greater in older than in younger boys, both in right and left hands. There were no differences between left and right hand measurements. There were positive correlations between Ad-SoS and shoulder muscle strength in boys. Negative correlations between Ad-SoS at phalanges of right and left hand and BMI were shown in younger adolescent boys only. Similarly, only in the younger group were positive correlations present between both hands Ad-SoS and overall physical efficiency and age. Ad-SoS correlated positively better with Tanner's scale scoring in the older group.

Conclusions: QUS at hand phalanges in adolescent boys aged 13-15 years depends on pubertal development and shoulder muscle strength. The overall physical efficiency has limited influence on bone properties assessed by QUS. (Endokrynol Pol 2013; 64 (5): 353-357)

Key words: bone quantitative ultrasound, pubertal development, physical efficiency, children
\end{abstract}

\section{Streszczenie}

Wstęp: Celem badań była ocean właściwości ultradźwiękowych kości paliczków rąk u 55 chłopców w wieku 13-15 lat zależnie od stopnia dojrzałości płciowej, wydolności fizycznej w tym siły mięśniowej.

Material i metody: Badani zostali podzieleni na dwie grupy wiekowe: podgrupa I ( $\mathrm{n}=37)$, chłopcy w wieku 159-171 miesięcy i podgrupa II $(\mathrm{n}=18)$, badani w wieku 172-184 miesiące. Grupę kontrolną stanowiło 94 chłopców dobranych pod względem wieku z liczącej 1256 osoby grupy badanych w celach skriningowych. Stan szkieletu (zależna od amplitudy szybkość dźwięku - Ad-SoS) był oceniany za pomocą ilościowej ultrasonografii (QUS) paliczków bliższych aparatem DBM Sonic 1200. Wydolność fizyczna była badana za pomocą testu Zuchory, rozwój płciowy w oparciu o skalę Tannera.

Wyniki: Nie wykazano różnic w średnich Ad-SoS między grupą badaną w całości a grupą kontrolną. Wartości Ad-SoS były większe u starszych chłopców, zarówno w prawej, jak i lewej ręce. Nie stwierdzono różnic pomiędzy pomiarami lewej i prawej ręki. Obserwowano dodatnią zależność między Ad-SoS a siłą mięśni ramion u chłopców. Ujemne zależności między Ad-SoS paliczków lewej i prawej ręki, a BMI wykazano jedynie w grupie młodszych chłopców. Podobnie w grupie młodszej obserwowano dodatnie zależności między Ad-SoS obu rąk a wydolnością fizyczną. Wykazano większą zależność Ad-SoS od stopnia rozwoju płciowego w skali Tannera w starszej grupie. Wnioski: Badanie QUS paliczków u dorastających chłopców w wieku 13-15 lat zależy od rozwoju płciowego i siły mięśni ramion. Ogólna wydolność fizyczna ma ograniczony wpływ na właściwości kości badane przez QUS. (Endokrynol Pol 2013; 64 (5): 353-357)

Słowa kluczowe: ilościowa ultrasonografia kości, dojrzewanie płciowe, wydolność fizyczna, dzieci

\section{Introduction}

Skeletal growth in children and adolescents depends on many factors including genetic, environmental and hormonal ones. The final bone mass and mineralisation is influenced by the occurrence of puberty at the right time and normal hormonal status regarding growth hormone and thyroid hormones secretion. Bones size 
and mass are correlated with body size, physical activity and muscle strength [1,2]. Delayed puberty, growth hormone deficiency, hypothyroidism and other diseases can result in lower bone mass and size. Decreased mechanical properties of bones assessed by ultrasound have been shown in children and adolescents suffering from different diseases, for example chronic renal failure or leukemia survivors [3-5].

Ultrasound measurement of skeletal properties of bones using a portable device is a safe, non-invasive and easily available way of giving additional information on bone strength and elasticity. The phalangeal quantitative ultrasound (QUS) measurement was introduced more than a decade ago and has been validated in various clinical studies [6-9]. This technique, by measuring the amplitude-dependent speed of sound, may provide useful information not only on bone mass but also on bone tissue architecture and elasticity. The ability of ultrasound measurements to detect bone growth and ageing and to assess fracture risk in various metabolic bone diseases was presented in a review [10]. Among other studies, phalangeal ultrasound measurements were also used in the detection of various hormonal disorders $[11,12]$. There are differences among studied populations, and there is no available data on ultrasound measurements of phalangeal bones in healthy adolescents of the Lower Silesia region. There have only been studies carried out in an Upper Silesia population [13, 14]. Assessments of QUS and physical efficiency in children are extremely rare. The only known study showed a negative correlation between moderate physical activity and QUS results of tibia and radius in younger girls, aged 9-13 years [15].

The aim of our study was to assess the ultrasound properties of bone measured at hand phalanges in adolescent boys regarding the influence of pubertal status and level of physical efficiency including muscular strength.

\section{Material and methods}

\section{Subjects}

The study was carried out in 55 adolescent boys aged $13.25-15.3$ years, mean age $14.1 \pm 0.25$ years $(169.3 \pm 6.3$ months), the pupils of classes 1 and 2 of the secondary school in a small city of the Lower Silesia region (Chocianów). All of them were healthy, without any longterm medication. The subjects studied were divided regarding school classes level into two groups: Group I (those attending class I, $\mathrm{n}=37$ ) and Group II (those attending class II, $\mathrm{n}=18$ ). The control group consisted of 94 boys matched for age. The controls were recruited from a group of 1,256 subjects undergoing bone mea- surement for screening purposes in the Metabolic Bone Diseases Unit. The general anthropometric characteristics of subjects studied are presented in Table I. The current study was a part of the school children studies entitled 'The Year of Health' programme.

All subjects (patients and controls) were interviewed by a physician using a special questionnaire in order to collect data on pubertal and general health status, family diseases and the occurrence of fractures among family members. Subjects with factors with a potential influence on bone metabolism (either prolonged diseases of the thyroid gland, liver, kidney, gastrointestinal surgery or medications using corticosteroids, anticonvulsants, thyroid hormone etc. or those being treated with any drugs for osteoporosis) were not included (in subjects or controls). Parents gave written consent for the participation of their children in the study. The Local Ethics Committee gave its approval for the study protocol.

\section{Methods}

\section{Anthropometric measurements}

In all subjects, weight, height, and body mass index (BMI) i.e. weight in kilograms divided by height squared $\left(\mathrm{kg} / \mathrm{m}^{2}\right)$ were established. Information concerning hand dominance was obtained from all of subjects. All but one of the subjects was right-handed, and he was excluded from the analysis.

\section{QUS measurement}

The skeletal status was assessed by QUS measurements at proximal phalanges with the use of the DBM Sonic 1200 device (IGEA, Carpi, Italy). The unit consists of two probes mounted on an electronic caliper, one emitter and another receiver. The latter records the ultrasound energy after it has crossed the phalanx. The amplitude-dependent speed of sound (Ad-SoS, in $\mathrm{m} / \mathrm{s}$ ) was determined in the distal metaphyses of the proximal phalanges in the second through fifth fingers of the dominant hand. The SoS in bone tissue was calculated considering the first signal with an amplitude of at least $2 \mathrm{mV}$ at the receiving probe; thus, the measured SoS is amplitudedependent. Acoustic coupling was achieved with a standard ultrasound gel. The precision of QUS measurements, expressed in variation coefficient (CV\%), was $0.64 \%$. CV\% was established on the basis of 75 bone scans with repositioning of the device caliper (five measurements in each subject). The detailed methodology was as described by Pluskiewicz and Drozdzowska [9]. All measurements, as well as all scans in controls, were done by one experienced operator (WP). 


\section{Physical activity questionnaire}

The study used a questionnaire to assess the physical activity of the boys. The overall physical efficiency was determined using the Zuchora's Index of Physical Efficiency. The test consisted of six trials to establish an overall physical efficiency (speed, jumping ability, flexibility, shoulder muscular strength, abdominal muscle strength, endurance) defined on a scale of 1-6 (with six equating to excellent). This test is standardised regarding age, and calculations of the results are age- and height-dependent [16].

\section{Tanner staging analysis}

Pubertal status was based on Tanner's staging, which is assessed on genital (G1-G5) and pubic hair (P1P5) stages ( 1 being no development and 5 being the highest level of pubertal development) [17]. This was self-reported by boys and ascertained by an assisting physician.

\section{Statistical analysis}

All statistical analyses were carried out using Statistica 10. Analysed data was presented as mean values and standard deviations (SD). Differences between groups studied were assessed using Student's t-test for independent samples (for normally distributed data) or Mann-Whitney U-test (for non-normally distributed data). The correlations between variables analysed were calculated according to Spearman's or Pearson's tests as appropriate. Stepwise multiple regression analysis was used to identify factors influencing Ad-SoS value in patients and controls. All results were considered as statistically significant at $\mathrm{p}<0.05$.

\section{Results}

Despite being the same age and of similar height, adolescent boys from our study group (Chocianów) had greater body weight and BMI values than controls from Upper Silesia. There was no difference in the mean Ad-SoS between the entire study group and controls (Table I).

There was a significant difference in Ad-SoS values when the study group was divided into age groups. Moreover, the older adolescent boys (class II) had greater height, weight, pubertal development assessed by Tanner's staging, and overall general efficiency score than their younger colleagues (class I). These differences are presumably due to the one year difference in age between them (Group I v. Group II, $165.68 \pm 3.59$ and $176.78 \pm 3.3$ months, respectively) (Table II).

When right and left hand Ad-SoS in different age groups were compared, the values were greater in older boys than younger ones, both in right and left hand
Table I. General anthropometric characteristics of entire study group and controls, and their results of Ad-SoS at dominant hand phalanges (data presented as mean $\pm S D$ )

Tabela I. Ogólna charakterystyka antropometryczna i wyniki Ad-SoS paliczków dominującej ręki całej grupy badanej i grupy kontrolnej (średnia $\pm S D$ )

\begin{tabular}{lccc}
\hline & Study group & Control group & p \\
\hline Height $[\mathrm{cm}]$ & $166.9 \pm 8.29$ & $164.31 \pm 8.93$ & 0.091949 \\
\hline Weight $[\mathrm{kg}]$ & $59.07 \pm 13.42$ & $53.20 \pm 9.84$ & 0.003226 \\
\hline BMl $\left[\mathrm{kg} / \mathrm{m}^{2}\right]$ & $21.09 \pm 3.94$ & $19.57 \pm 2.49$ & 0.005399 \\
\hline Ad-SoS $[\mathrm{m} / \mathrm{s}]$ & $1.983 .47 \pm 65.85$ & $1.983 .47 \pm 54.50$ & 0.999630 \\
\hline
\end{tabular}

Table II. Comparison of anthropometric data, pubertal development, general physical efficiency Ad-SoS between groups of adolescent boys (presented as mean $\pm S D$ )

Tabela II. Porównanie danych antropometrycznych, dojrzewania ptciowego, ogólnej sprawności fizycznej i wyników Ad-SoS w grupach dorastajacych chłopców (średnia $\pm S D$ )

\begin{tabular}{lccc}
\hline & Group I ( $\mathbf{n}=\mathbf{3 7})$ & Group II (n = 18) & $\mathbf{p}$ \\
\hline Age (months) & $165.68 \pm 3.30$ & $176.78 \pm 1.18$ & 0.000000 \\
\hline Height [cm] & $163.71 \pm 6.85$ & $174.33 \pm 6.48$ & 0.000006 \\
\hline Weight $[\mathrm{kg}]$ & $56.55 \pm 13.32$ & $64.95 \pm 12.08$ & 0.041197 \\
\hline BMI $\left[\mathrm{kg} / \mathrm{m}^{2}\right]$ & $20.96 \pm 3.96$ & $21.40 \pm 4.01$ & 0.721288 \\
\hline Tanner's score & $3.97 \pm 0.71$ & $4.41 \pm 0.51$ & 0.001932 \\
\hline $\begin{array}{l}\text { Overall physical } \\
\text { efficiency }\end{array}$ & $2.36 \pm 1.01$ & $3.23 \pm 1.17$ & 0.009126 \\
\hline $\begin{array}{l}\text { Ad-SoS [m/s] } \\
1.958 .70 \pm 56.02\end{array}$ & $2.034 .39 \pm 55.19$ & 0.000017 \\
\hline
\end{tabular}

phalanges ( $\mathrm{p}=0.000017$ and 0.000019 , respectively). All subjects studied were right-handed, one left-handed boy was excluded from the analysis. There were no differences between measurements done in left and right hands (Fig. 1).

There were positive correlations between Ad-SoS and shoulder muscle strength in both hand measurements in both groups of boys. Negative correlations between the values of Ad-SoS at phalanges of right and left hand and BMI were shown in younger adolescent boys only. Similarly, only in the younger group there were positive correlations between both hands Ad-SoS and overall physical efficiency, jumping ability and age. Ad-SoS correlated positively better with Tanner's scale scoring in Group II than in Group I, where it was present only in the right hand (Table III). No correlations were observed between QUS results and other elements of the physical efficiency test (abdominal muscle strength, speed, flexibility, and endurance). 


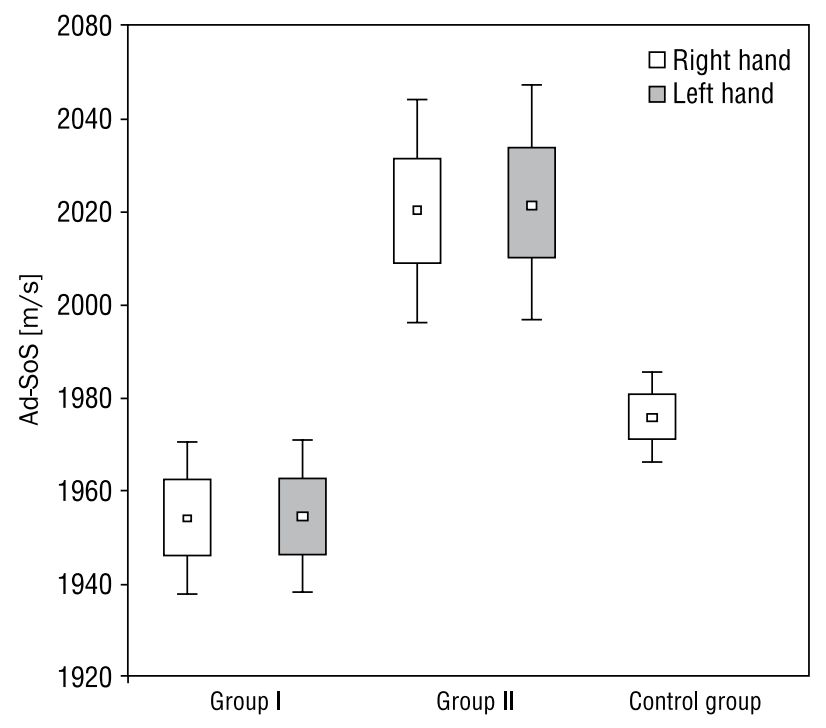

Figure 1. Ad-SoS at hand phalanges in study group and controls, regarding left and right hand measurements (for study groups I and II) in relation to the controls

Rycina 1. Ad-SoS paliczków rąk w grupach badanej i kontrolnej, pomiary obu rąk (grupa badana I i II) w porównaniu z grupa kontrolna

A negative correlation was found between BMI and shoulder muscle strength $(\mathrm{r}=-0.501709)$, but not with overall physical efficiency nor Tanner's scores. The overall physical efficiency correlated strongly positively with shoulder muscle strength $(\mathrm{r}=0.764572)$, of course. Tanner's scoring correlated positively with overall physical efficiency $(r=0.367968)$, but not with shoulder muscle strength nor with age.

Stepwise regression analysis showed statistically significant influence of age, overall efficiency, height and body mass on Ad-SoS (Table IV). When particular elements of the physical efficiency test were analysed, there was a very strong influence of shoulder muscle strength $(p=0.000009$ for right hand and $p=0.000004$ for left hand, respectively) on Ad-SoS.

\section{Discussion}

This cross-sectional study was performed in order to assess the ultrasound properties of bone measured at hand phalanges in adolescent schoolboys from a particular city regarding the influence of pubertal status, level of physical efficiency, physical activity and muscular strength. The subjects originated from the small city of Chocianów (8,000 inhabitants) located on the borderline of the copper industry area (copperworks and mines). The possible influence of heavy metals on bones should be taken into consideration.

We showed greater body weight and BMI in our group than the controls from Upper Silesia, despite the same age and similar height. Adolescents from the study

Table III. Correlation coefficients (r) between Ad-SoS measurements and BMI values, Tanner's scores and overall physical efficiency for right and left hand measurements in boys from studied groups

Tabela III. Wspótczynniki korelacji (r) między pomiarami Ad-SoS oraz wartościami BMI, skali Tannera i ogólnq sprawnościq fizyczną dla pomiarów prawej i lewej ręki u chłopców z badanych grup

\begin{tabular}{lcccc}
\hline & & Group I & Group II \\
\hline BMI & Right & Left & -0.289804 & -0.316354 \\
\hline Overall physical efficiency & -0.455425 & -0.492257 & 0.456214 & 0.385496 \\
\hline Shoulder strength & 0.474501 & 0.475556 & 0.628512 & 0.627646 \\
\hline Jumping ability & 0.520701 & 0.532713 & 0.513250 & 0.489636 \\
\hline Age & 0.347899 & 0.366971 & 0.158400 & 0.220495 \\
\hline Tanner's score & 0.426550 & 0.452228 & 0.598473 & 0.622518 \\
\hline
\end{tabular}

Table IV. Stepwise regression analysis for right and left side Ad-SoS and age, general efficiency, body mass, height and Tanner's score Tabela IV. Analiza regresji krokowej dla Ad-SoS prawej i lewej ręki oraz wieku, ogólnej sprawności fizycznej, masy ciała, wzrostu i skali Tannera

\begin{tabular}{lccccc}
\hline & Age & Overall efficiency & Height & Body mass & Tanner's scale \\
\hline Step No & 1 & 2 & 3 & 4 & 5 \\
\hline Ad-SoS right & 0.000004 & 0.012084 & 0.018737 & 0.008064 & 0.069288 \\
\hline Ad-SoS left & 0.000004 & 0.007774 & 0.013392 & 0.007371 & 0.098043 \\
\hline
\end{tabular}


group had a better nutrition status, but it was normal in the majority of them. Only in five $(9 \%)$ of our subjects was body mass outside the normal range (3-97 centiles). This could be due to the better economic situation of the population living in this region. Moreover, the school in Chocianów participated in European programmes on healthy nutrition, which could be another important factor. On the other hand, it is well known that diseases, malabsorption syndromes, and poor nutrition can worsen bone status [3-5, 18].

Despite these differences, the mean Ad-SoS values were almost identical as in the much more numerous control group. The higher BMI and body mass did not influence the bone QUS measurements in our subjects. Our subjects were 13-plus years old; this is the borderline of the beginning of Ad-SoS acceleration documented in adolescent boys from an Upper Silesia population [13, 14]. The positive influence of age on Ad-SoS is observed at age 11-16 years [19]. The planned follow-up study can assess possible increments in bone parameters studied.

The dominant hand Ad-SoS of our subjects did not differ from the results reported by other authors. Similar values were observed by Halaba and Pluskiewicz in children and adolescents from Upper Silesia, both urban and rural areas [19]. So, the industrial influences in the latter population and in our subjects could be either similar or not significant. The data from other countries regarding bone QUS results is comparable to ours [20-23].

Older adolescents had greater body size than younger ones; this is true for Ad-SoS results, overall physical efficiency and pubertal development, too. The level of pubertal development of all adolescent boys was high, normal for their age. Interestingly, boys with higher BMI had lower Ad-SoS. The positive influence of body weight on Ad-SoS, but negative one of height and BMI in boys, is known from other studies $[8,13]$.

The coefficients of correlation ( $r$ ) between Ad-SoS and muscular strength or pubertal development are higher in older than in younger boys. This shows the impact of pubertal development and shoulder muscle strength on bone size and strength.

Although the overall physical efficiency had limited influence on bone properties assessed by QUS, the overall general efficiency is described by Zuchora's test on the basis of shoulder muscular strength which is the major influencing factor [16]. This indicates the possible influence of physical activity and sexual maturation on bone structure [2]. On the other hand, physical activity might influence sexual development, since our subjects reported quite a high level of physical activity. Our stepwise regression analysis showed the potent influence of shoulder muscle strength on Ad-SoS; this was not present in the case of pubertal development assessed by Tanner's scoring.
In conclusion, QUS at hand phalanges in adolescent boys aged 13-15 years depends on pubertal development and shoulder muscle strength. The overall physical efficiency has limited influence on bone properties assessed by QUS.

\section{References}

1. Cadossi R, de Terlizzi F, Cane V et al. Assessment of bone architecture with ultrasonometry: Experimental and clinical experience. Horm Res, 2000; 54 (Suppl. 1): 9-18.

2. Boot AM, de Ridder MA, Pols HAP et al. Bone mineral density in children and adolescents: Relation to puberty, calcium intake, and physical activity. J Clin Endocrinol Metab 1997; 82: 57-62.

3. Pluskiewicz W, Adamczyk P, Drozdzowska B et al. Skeletal status in adolescents with end-stage renal failure: A longitudinal study. Osteoporos Int 2005; 16: 289-295.

4. Chobot AP, Haffke A, Polańska J et al. Bone status in adolescents with type 1 diabetes. Diabetologia 2010; 53: 1754-1760.

5. Pluskiewicz W, Halaba Z, Chełmicka L et al. Skeletal status in survivor of acute lymphoblastic leukemia assessed by quantitative ultrasound at the hand phalanges: A longitudinal study. Ultrasound Med Biol 2004; 30: 893-898.

6. Wüster C, Albanese C, de Aloysio D et al. Phalangeal osteosonogrammetry study: Age-related changes, diagnostic sensitivity, and discrimination power. J Bone Miner Res 2000; 15: 1603-1614.

7. Bolanowski M, Chwałczyńska A, Pluskiewicz W. Bone quantitative ultrasound at hand phalanges of women following breast cancer surgery. Gynecol Endocrinol 2011; 27: 1048-1051.

8. Ventura V, Mauloni M, Mura $\mathrm{M}$ et al. Ultrasound velocity changes a the proximal phalanges of the hand in pre-, peri- and postmenopausal women. Osteoporos Int 1996; 6: 368-375.

9. Pluskiewicz W, Drozdzowska B. Ultrasound measurements of proximal phalanges in polish early postmenopausal women. Osteoporos Int 1998; 8: 578-583.

10. Drozdzowska B, Pluskiewicz W, Halaba Z et al. Quantitative ultrasound at the hand phalanges in 2850 females aged 7 to $77 \mathrm{yr}$ : A cross-sectional study. J Clin Densitom 2005; 8: 216-221.

11. Gonnelli S, Montagnani A, Cepollaro C et al. Quantitative ultrasound and bone mineral density in patients with primary hyperparathyroidism before and after surgical treatment. Osteoporos Int 2000; 11: 255-260.

12. Bolanowski M, Pluskiewicz W, Adamczyk P et al. Quantitative ultrasound at the hand phalanges in patients with acromegaly, Ultrasound Med Biol 2006; 32: 191-195.

13. Halaba Z, Pluskiewicz W. The assessment of development of bone mass in children by quantitative ultrasound through the proximal phalanges of the hand. Ultrasound Med Biol 1997; 23: 1331-1335.

14. Halaba ZP. Quantitative ultrasound measurements at hand phalanges in children and adolescents: A longitudinal study. Ultrasound Med Biol 2008; 34:1547-1553.

15. Baptista F, Fragoso I, Branco J et al. Reference data for bone speed of sound in Portuguese girls and boys aged 9-13 years. J Clin Densitom 2011; 14: 484-491.

16. Januszewski J, Mleczko M, Nieroda R. Triple- and double-compound morphological age in evaluation of selected components of physical fitness in girls under the terms of health-related fitness (H-RF). Antropomotoryka 2010; 20: 17-38.

17. Tanner JM, Whitehouse RH. Clinical longitudinal standard of height, weight, height velocity and stages of puberty. Arch Dis Child 1976; 51 170-179.

18. Szymczak J, Bohdanowicz-Pawlak A, Waszczuk E et al. Low bone mineral density in adult Patient with coeliac disease. Endokrynol Pol 2012; 63: 270-276.

19. Halaba ZP, Pluskiewicz W. Quantitative ultrasound in the assessment of skeletal status in children and adolescents. Ultrasound Med Biol 2004; 30: 239-243.

20. Baroncelli GI, Federico G, Bertelloni S et al. Bone quality assessment by quantitative ultrasound of proximal phalanxes of the hand in healthy subjects aged 3-21 years. Pediatr Res 2001; 49: 713-718.

21. Lappe JM, Stegman MR, Davies KM et al. A prospective study of quantitative ultrasound in children and adolescents. J Clin Densitom 2000; 2: 167-175.

22. Barkmann R, Rohrschneider W, Vierling M et al. German pediatric reference data for quantitative transverse transmission ultrasound of finger phalanges. Osteoporos Int 2002; 13: 55-61.

23. Gimeno-Ballester J, Azcona San Julian C, Sierrasesumaga Ariznabarreta $\mathrm{L}$. Bone mineral density determination by osteosonography in healthy children and adolescents: normal values. An Esp Pediatr 2001; 54: 540-546. 